\title{
衛星画像を用いた植生分布の 空間的な集積状態とその恋遷の分析
}

\author{
植松 恒 $^{1} \cdot$ 松田 優花 ${ }^{2} \cdot$ 熊谷 $_{\text {樹一郎 }}^{3}$ \\ 1学生員 摂南大学大学院 工学研究科創生工学専攻（†572-8508 大阪府寝屋川市池田中町 17-8) \\ E-mail: 13d301uh@edu.setsunan.ac.jp \\ 2学生員 摂南大学大学院 理工学研究科社会開発工学専攻 ( $=572-8508$ 大阪府寝屋川市池田中町 17-8) \\ E-mail: 15m206my@edu.setsunan.ac.jp \\ 3 正会員 摂南大学教授 理工学部都市環境工学科（†572-8508 大阪府寝屋川市池田中町 17-8） \\ E-mail: kumagai@civ.setsunan.ac.jp
}

\begin{abstract}
都市の緑地などの植生群を保全・創出していくには，個々の植生分布の空間的な位置関係を考慮した現 状を広範囲から把握する必要がある。我々は, 衛星デー夕から算出したNDVIに空間的自己相関分析を応 用することで, 植生被覆量の多い籄所から少ない箇所へと植生分布が空間的に連なる箇所を植生分布変移 軸と定義し, 抽出する分析手法を開発してきた。本研究では, 都市整備の進渉と植生分布の変遷との関係 を広域的に把握することを目指し，2000 年と 2013 年の観測時期の異なる衛星データから得た NDVI を基 に 2 時期での植生分布の集積状態と植生分布変移軸を比較した。そその結果, 植生被覆量の多い箇所の集積 する領域が限定されてきており, 縮小や分断といった変化が植生分布の空間的な連なりに影響を及ぼて いる可能性が示唆された.
\end{abstract}

Key Words: : normalized difference vegetation index, spatial autocorrelation, vegetation distribution, spatial characteristic, secular variation

\section{1.はじめに}

現在，日本国内では少子高齢化社会を迎えつつあ るなかで, 集約型都市構造への転換が提唱され，多 極ネットワーク型コンパクトシティの実現へ向けた 施策が立てられてきている11)。その一方で，長期間 にわたる都市構造の集約化のなかで，増加の見込ま れる空き地などといったオープンスペースの扱いに ついては問題点が不明確であるなど, 議論の余地が 多い。具体的な施策を立てていくなかでマク口的な 視点の必要性が指摘されており, 都市全体の空間の 中でのオープンスペースの役割をネットワークとし て見ていくことが望まれている2),3).

オープンスペースの代表的な土地利用形態として 緑地が挙げられる。特に, 植生の分布状態について は, 都道府県広域緑地計画などでの「みどりの将来 像図」では大規模な植生群を拠点とする緑のネット ワークを形成するように，植生分布の保全や緑化の 推進を重点的に行う地域などを取り決めている4). 緑のネットワークは，植生分布が連なりを形成する
ことで，生物の育成の場としての機能や周辺の市街 地の気温を低減するといった緑の効果を期待した計 画である ${ }^{5), 6)}$ 。一方で，ネットワークを構成する基 となるのは，道路や河川といった都市施設であるこ とが多く，必ずしも植生分布そのものが反映された ものではない.

これまで我々は，空間的自己相関分析を応用した 空間分析手法に地球観測衛星デー夕 (以降, 衛星デー 夕と呼ぶ）から算出した NDVI (Normalized Difference Vegetation Index：正規化植生指数）を適用 することで，植生分布の空間的な連なりを広範囲か ら抽出する分析手法の開発を試みてきた ${ }^{7)}$. NDVI を植生被覆量の代替值として採用した上で，植生被 覆量の多い箇所から少ない箇所へと連なる植生分布 を植生分布変移軸として定義・抽出し, 緑のネット ワークに対する新たなモニタリングの視点を提供し ている。

将来の都市像を想定した緑地などの配置計画を策 定していくには, 都市構造の変化とともに植生分布 の集積や分断，さらにはネットワークの形成状態の 
変遷もモニタリングしていくことが望まれる。本研 究では複数の観測時期の衛星デー夕を適用した上 で，植生分布の空間的な連なりに生じた変化の抽出 を試みるとともにその内容を明らかにした。

\section{2. 対象領域および対象データの選定}

\section{（1）対象領域}

対象領域として, 大阪府北部 $(30 \mathrm{~km} \times 25 \mathrm{~km})$ を選 定した，大阪府北部は大阪府中心部のベッドタウン として発達し, 豊かな自然をあわせ持つ地域であり, 植生が多様な形態で分布している。 その一方で，近 年では中心市街地の再開発や郊外のニュータウン型 の開発, 高速道路の建設が進められており, 都市整 備の活発な地域でもある。

\section{（2）対象データ}

広域的な植生分布の変遷の把握を前提として, 対 象領域を一度に観測できる 2000 年 8 月 25 日観測の Landsat-7 ETM +データと 2013 年 7 月 20 日観測の Landsat-8 OLI データ（ともに空間分解能： $30 \mathrm{~m} \times$ $30 \mathrm{~m})$ とを対象データとして採用した。

\section{(3) NDVIの取り扱い}

本研究では, 植生被覆量を代替する指標として衛 星データから得られたNDVIを採用している. NDVI は式（1）のように計算される植生の活性度を 表す指標である ${ }^{8)}$.

$$
N D V I=\frac{R_{\mathrm{NIR}}-R_{\mathrm{RED}}}{R_{\mathrm{NIR}}+R_{\mathrm{RED}}}
$$

ただし， $R_{\mathrm{RED}}$ は赤色波長域， $R_{\mathrm{NIR}}$ は近赤外域の反 射率を表す。一方で, 衛星画像から得られた NDVI は植生被覆量と強い相関があることが知られてお り, 広範囲からの緑被率の推定に採用されてい る ${ }^{9)-11)}$. 本研究では前処理として MODTRANに基 づいた大気補正処理を行った後, NDVIを算出して いる. NDVI は衛星デー夕の画素単位で計算される ことになるが，その画素值は必ずしも観測したセン サの空間分解能で規定される地上での大きさを代表 した值とはならないとの指摘がある ${ }^{11)}$ 。そこで, 本 研究では 2001 年 10 月 3 日に観測された IKONOS 画 像（空間分解能: $4 \mathrm{~m} \times 4 \mathrm{~m}$ ）を目視判読することによ り作成した植生被覆率データと Landsat ${ }^{-7}$ ETM + データから算出したNDVI とを空間分解能を変化さ せながら比較し，最も相関係数が高い值を示した $60 \mathrm{~m} \times 60 \mathrm{~m}$ を NDVIの空間分解能として採用し
た 夕についても 2000 年観測の衛星デー夕の画素と同 等の大きさを網羅すると仮定し, NDVI の空間分解 能を $60 \mathrm{~m} \times 60 \mathrm{~m}$ と設定している.

\section{3. 植生分布の空間的な連なりの抽出}

\section{（1）植生分布の空間的な分布状態の把握}

空間的自己相関分析を応用した分析手法に衛星 データから算出したNDVIを適用することで植生分 布の空間的な分布状況を把握する。本研究での空間 分析手法として, 局所領域での空間属性の分布パ ターンを分析する $\mathrm{G}$ 統計量を採用した。地点 $i$ にお ける $\mathrm{G}$ 統計量は次式で与えられる12).

$$
G_{i}(d)=\frac{\sum_{j} w_{i j}(d) x_{j}}{\sum_{j} x_{j}} \quad i \neq j
$$

局所的な空間的自己相関測度 $G_{i}(d)$ は, 地点 $i$ の 半径 $d$ 領域内に位置する点の属性值 $x_{j}$ の合計值を全 地点の点属性值 $x_{j}$ の合計值で割る比率で表される統 計量である. $w_{i j}(d)$ は地点 $i$ から半径 $d$ 内に地点 $j$ が属するか否かを判定する重み係数である， $G_{i}(d)$ からは検定統計量が計算され, 本研究であれば注目 する画素の中心から半径 $d$ 領域内に NDVI の高い画 素が集積すると「正の空間的自己相関あり」, NDVI の低い画素が集積すると「負の空間的自己相関あ り」, NDVI の高い画素と低い画素が混在する場合は 「空間的自己相関なし」に画素ごとに判定される。な お， $x_{j}$ は正の值を対象とすることから，ここでは対象 領域内の全ての画素の NDVI をオフセット $(+1) し$, $\mathrm{NDVI}$ を 0 以上 2 以下の值に変更した上で $\mathrm{G}$ 統計量 を算出している。

本研究では, 局所的な範囲を可変とした上で, 注 目する画素を中心に狭めていきながら空間的自己相 関分析を実施し, 空間的自己相関測度を検定統計量 として算出する。有意水準は $10 \%$ としている。図-1 のように空間的自己相関分析の各範囲での判定結果 を仮想レイヤとして積み上げたものが SSC（Spatial Scale of Clumping）である ${ }^{7)}$. 具体的には「正の空間 的自己相関あり」と「負の空間的自己相関あり」の場 合のそれぞれについて, 最大の範囲での判定結果を 最下層と設定した上で，範囲を狭めるにつれて「空 間的自己相関あり」と判定されれば結果を積み上げ ていくことでSSC を作成する.

図-1（i）の（a）点は，その画素を中心に近傍から 遠方まで NDVI の高い画素が集積している地域を表 している。このような地点は正の SSC の層数が高い 
(i) 仮想レイヤの積み上げ

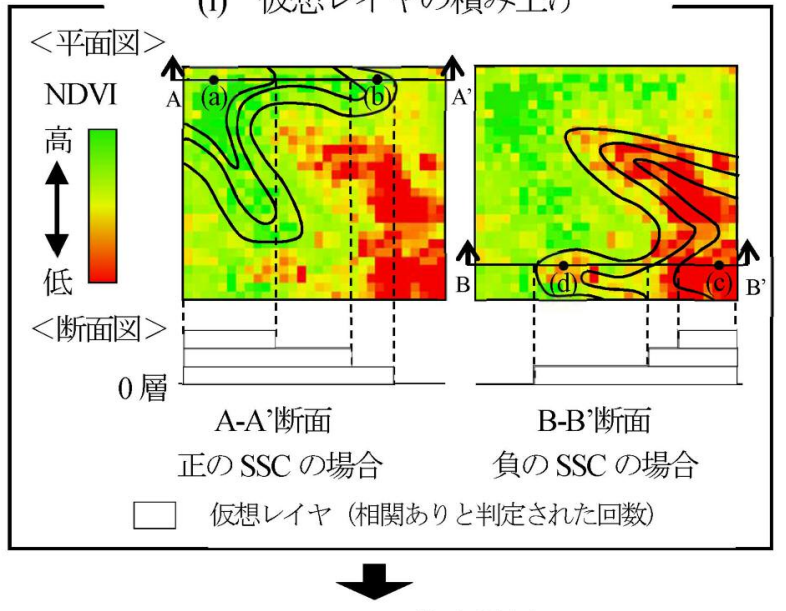

(ii) $\mathrm{SSC} の$ 作成結果
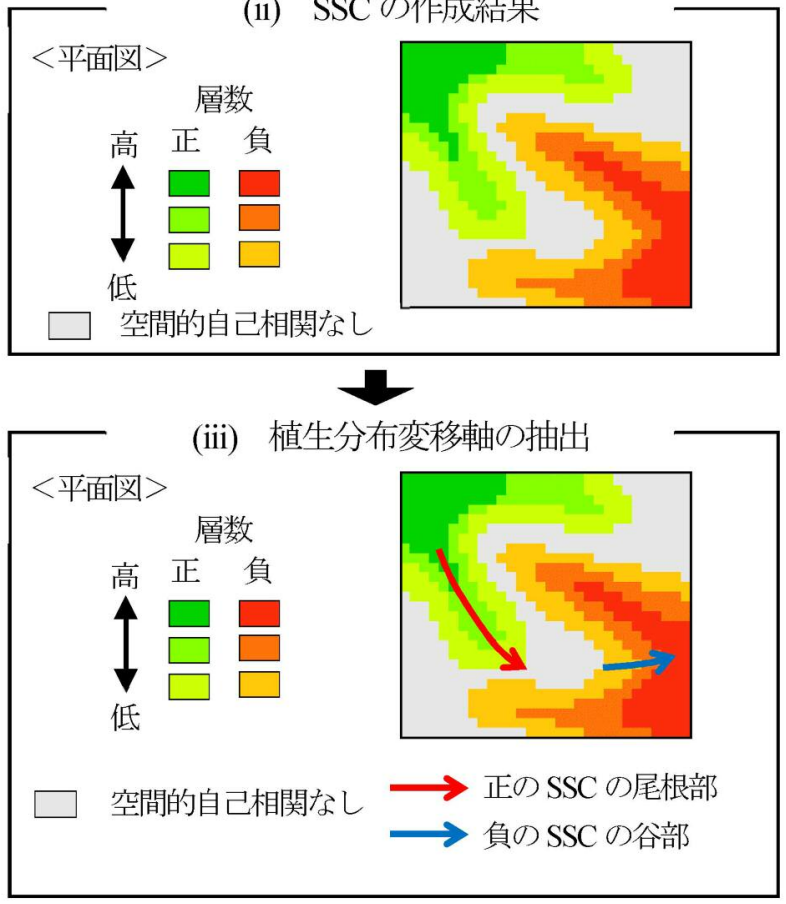

図-1 SSC の作成概念図

箇所となる. 図-1 (i) の（b) 点のような正の SSC の 層数の低い箇所は，注目する画素の近傍では NDVI の高い画素と低い画素が混在した状態となるもの の，画素中心から遠方までの範囲では NDVI の高い 画素が集積する地域である。つまり，正の SSC は層 数が高いほどその地点を中心に植生被覆量の多い箇 所が空間的に集まる傾向を示す．図-1（i）の（c）点 は，その画素を中心に近傍から遠方までNDVI の低 い画素が集積していることを表す地域である，負の SSCでは層数が高い箇所ほど, その地点を中心とし て近傍から遠方まで植生被覆量の少ない箇所が集ま る傾向を示す.

なお，SSCの作成には積み上げの基準となる最大 の範囲を設定する必要がある。本研究では最小の範 囲の半径 $d$ を 3 画素 $\times 3$ 画素のウィンドウサイズと 同等の $90 \mathrm{~m}$ とした上で, $d$ を増加させながら対象領
域の全体で空間的自己相関分析を実施し, 判定結果 の変化量が収束する傾向を調査した，半径 $d$ の増加 に伴う「正の空間的自己相関あり」，「負の空間的自 己相関あり」,「空間的自己相関なし」のそれぞれで の判別結果の面積率の差分が処理対象となる領域全 体の $0.3 \%$ 未満となる場合に収束していると判断し, 条件として設定した。最大の範囲を検討した結果, 2000 年では $1050 \mathrm{~m}, 2013$ 年では $1710 \mathrm{~m}$ で判別結果 が収束する傾向を示した，そこで，半径 $d=1710 \mathrm{~m}$ の SSC の層を積み上げる基準面として，2 時期共通 で採用するものとした，結果として，2000 年につい ては, 1050m〜1710m までは各層の形状に変化がな く, 垂直に重なっていることになる13).

\section{（2）植生分布変移軸の選定}

正・負の SSC はその層数の高低によって地形図の ように植生分布の連なり度合いを表現したものと見 なすことができる，そこでSSCに水文解析を応用す ることで植生分布の空間的な連なりを抽出した，正 の SSCでは尾根線を抽出した. 図-1（iii）の赤矢印 で示した正の SSC の尾根部は SSC が高い領域から 低い領域に向かうに連れて層の高さが低くなりにく い部分であり, 近傍から遠方までNDVIの高い画素 が集積した状態が維持されやすいことを意味する。 負の SSC では谷線を抽出した。図-1（iii）の青矢印 で示した負のSSCの谷部は, 都市部において希少な 植生分布の集まりが都心部などの植生被覆量の少な い領域に迫るように分布する箇所となる。本研究で は植生被覆量の多い箇所と少ない箇所の間での連な りの抽出を前提に, 正の SSC での尾根線と負の SSC での谷線のなかでも, SSC の斜面部分に位置し, か つ, 広域的分析の観点から $2 \mathrm{~km}$ 以上のものを植生分 布変移軸として定義・選定した。

水文解析によって尾根線や谷線を抽出するには, 集水面積を確定する必要がある。ここでは, 植生被 覆量の高い（あるいは, 低い) 箇所が集まっている場 所とまばらな場所とをつなぐ部分の分析となるた め, SSC の斜面での植生分布変移軸の現れ方に着目 する. 集水面積の絞り込みに伴い SSC の最上層内で の水系線の枝分かれが始まる集水面積を決定し, 尾 根線と谷線を抽出する值として採用した。 2000 年の 正の SSC から得られる尾根線は $1.314 \mathrm{~km}^{2}$ (365 画 素), 負の SSC から得られる谷線は $1.98 \mathrm{~km}^{2}$ (550 画 素), 2013 年の尾根線は $1.458 \mathrm{~km}^{2}$ (405 画素), 谷線 は $0.99 \mathrm{~km}^{2}$ (275 画素) の集水面積を採用している. 


\section{4. 植生分布の空間特性の変遷の把握}
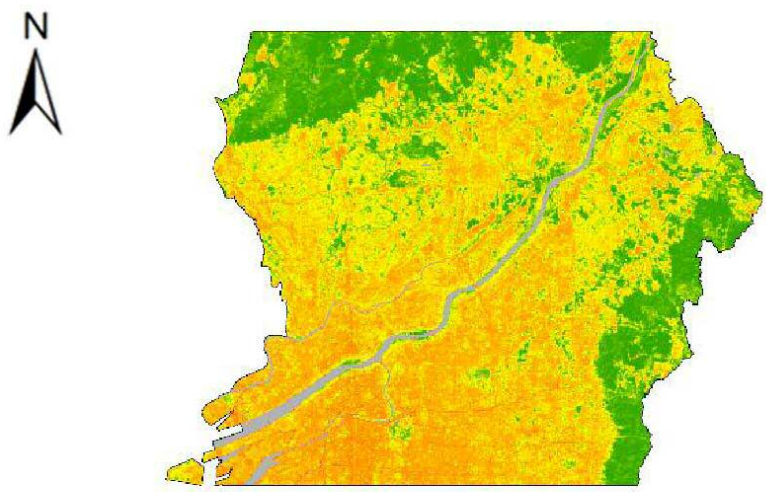

NDVI

(a) 2000 年

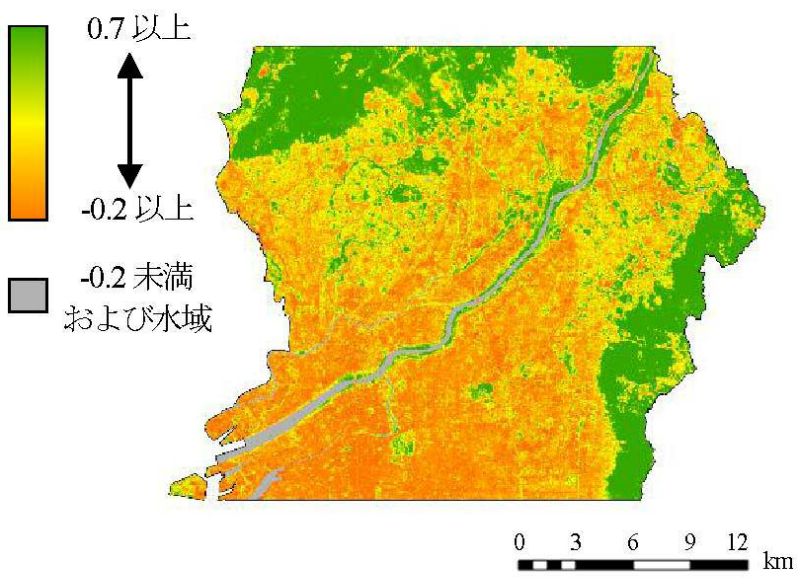

(b) 2013 年

図-2ＮDVI の算出結果

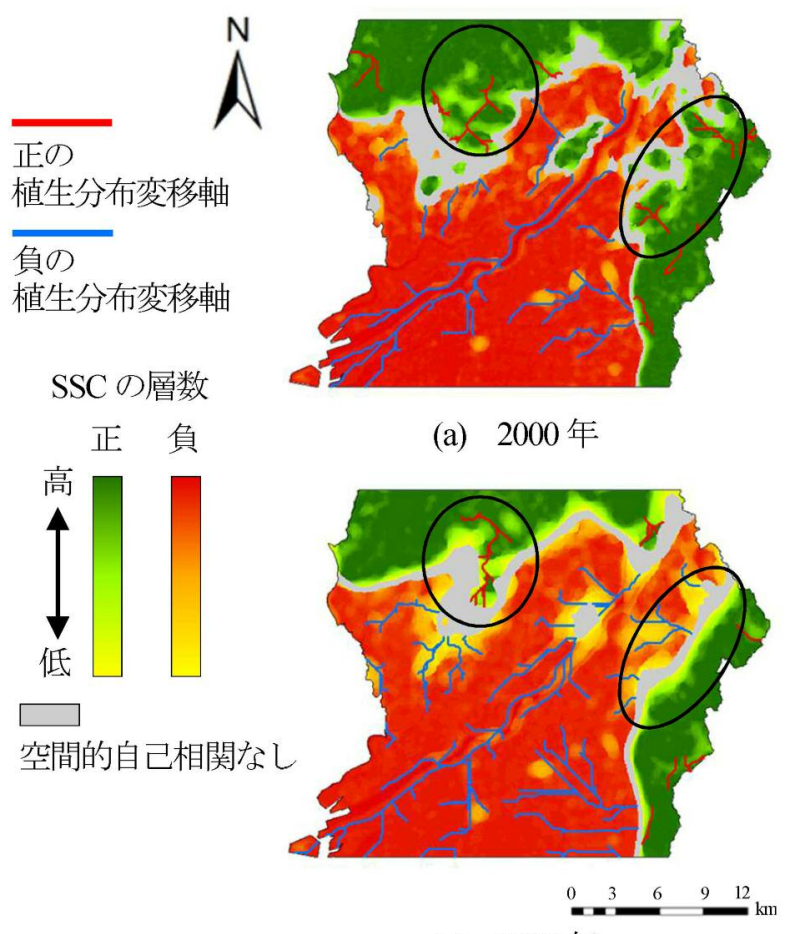

(b) 2013 年

図-3 SSC と植生分布変移軸の抽出結果

\section{（1） 2 時期での植生の分布状態の比較}

2000 年と 2013 年の NDVI の算出結果を図-2に, SSC の作成結果を図-3に示す。 2 時期の NDVI を比 較すると 2013 年の方が山岳部の一部や都市域で NDVI の低い值を示す傾向が確認できる，正と負の $\mathrm{SSC}$ の総面積を 2 時期で比較したところ，正の SSC の総面積は約 30\% 減少し, 負の SSC の総面積は約 $20 \%$ 増加していた．SSC の層数の分布状態の変化を 把握するために，SSC の各層の占める面積の構成比 を図-4の累積相対度数で比較した。図-4（a）の正の SSC においては, 2000 年と比べて 2013 年では最下 層の調査範囲が $1710 \mathrm{~m}$ と広がっているとともに，下 層部分の割合が増加することがわかる，正の SSCの 層数の低い箇所は調査範囲の広い場合にのみ正の空 間的自己相関ありと判定される地域である。正の SSC の推移を図-3で確認すると, 正の SSC そのもの の面積は減少しているなかで, 空間的自己相関なし との境界部分に層数の低いことを表わす黄緑色〜黄 色の部分が現れていることが確認できる。かつて近 傍から遠方に渡って植生被覆量の多い箇所が集積し ていると判定されていた箇所が，遠方まで範囲を広 げてはじめて植生被覆量の多い箇所が集まっている と判定されるように変化したと判断される。図-4 （b）の負のSSCにおいても2013 年で下層部分の割 合が多い傾向が見られた。負のSSCでは，総面積が 増加するとともに上層部分の占める割合が減少して いる。図-3の対象領域における分布では，負の SSC は都市部から郊外部へ範囲が広がる傾向が確認でき る．負の SSC の領域は植生分布のまばらであった箇 所が含まれるように広がったことが考えられる。

（2）植生分布変移軸の抽出箇所の特徵

a）植生分布変移軸の抽出状態

図-3に選定した植生分布変移軸について正の SSC から作成されるものを赤線, 負の SSC から作成され るものを青線で示す．図-3（a）の黒丸内の正の植生 分布変移軸を図-3（b）の 2013 年のものと比較する と, 北上し, 山岳部に移動する傾向や植生分布変移 軸そのものが消滅している箇所もみられる。図-3 （b）の負の植生分布変移軸の分布状態では，河川敷 を中心に都市域の全体に抽出箇所が広く分布するよ うに変化している傾向が確認できる．図-2 と比較す ると目視では NDVIの低い值の分布状態のなかで抽 出されている面もある。都市内の希少な植生分布の 連なりを抽出している可能性もあるが, NDVI の極 小さな值のみとなると分布の連なりを形成しうる植 


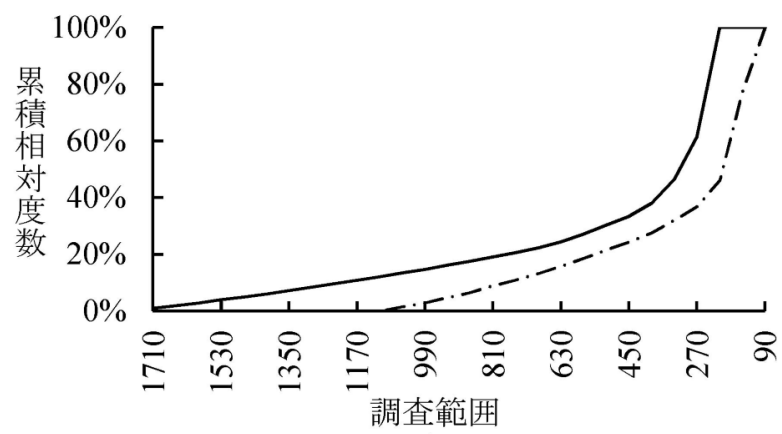

(a) 正のSSC

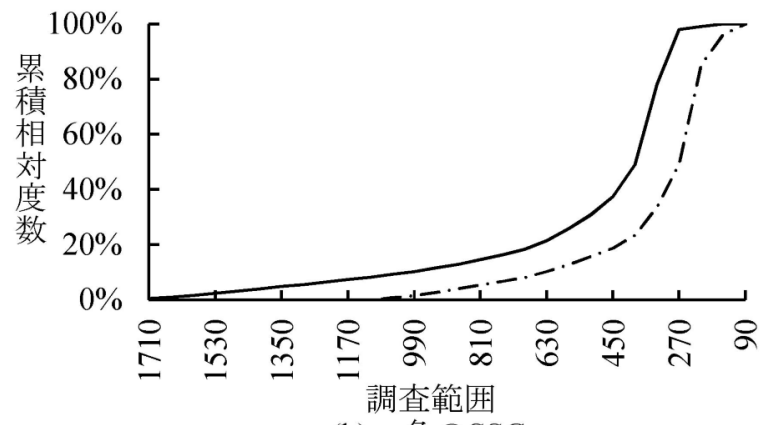

(b) 負のSSC

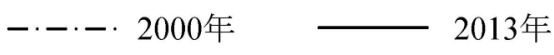

図-4 SSC の各層の構成比

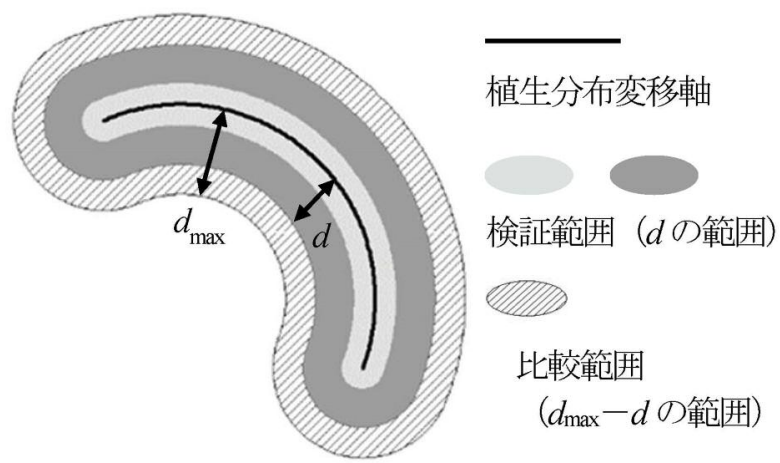

図-5 植生分布変移軸の検証方法

生そのものが存在するか否かといった点についても 注意が必要となる。本研究ではNDVIの分布状態に 検討の範囲を絞ることとし, 低いNDVIの分布と植 生の存在量との空間的な関連性については今後の課 題とする.

\section{b）検証方法の考え方}

本研究では, 植生分布変移軸の近傍と遠方の NDVI の平均值を統計的に比較することで，植生分 布の空間的な連なりの変遷について分析した。図-5 のように 2000 年および 2013 年の植生分布変移軸の それぞれから調査範囲（距離パラメータ $d$ までの範 囲）を「検証範囲」，各調査範囲 $d$ から最大の調査範 囲 $d_{\max }$ までの範囲を「比較範囲」と設定した。 $d_{\max }$ か ら $d$ を狭めながら各範囲における 2000 年抢よび 2013 年の NDVI の平均值を算出した。検証には
Welch 法に基づく 2 標本の差を利用した検定の考え を用いており，帰無仮説を「軸の近傍とそれ以外と ではNDVIの平均値に差はない」とした上で, 検証 範囲の NDVI の平均值と比較範囲の NDVI の平均值 の差を次式から検定統計量 $t_{0}$ として算出した.

$$
t_{0}=\frac{\bar{x}_{\text {in }}-\bar{x}_{\text {out }}}{\sqrt{\left(\frac{s_{\text {in }}{ }^{2}}{n_{\text {in }}}+\frac{s_{\text {out }}{ }^{2}}{n_{\text {out }}}\right)}}
$$

$\bar{x}_{i n} ， s_{i n}{ }^{2}$ および $n_{i n}$ は検証範囲に含まれる NDVI の 平均值，分散およびデー夕数を示し， $x_{\text {out }}, s_{\text {out }}^{2}$ およ び $n_{\text {out }}$ は比較範囲に含まれるNDVI の平均值, 分散 とデー夕数を示す.

\section{c）抽出手法の適用性の検証}

植生分布変移軸は，抽出箇所の近傍に NDVI の高 い画素が集積するとの仮定により抽出されている. 各植生分布変移軸と同時期の NDVI を使用し検証す ることで, 植生分布変移軸の抽出方法の適用性を明 らかにする，図-6 は正の植生分布変移軸について検 証範囲に含まれる NDVI の平均値と比較範囲に含ま れる NDVIの平均值の差を式（3）より検定統計量と して算出し，検証範囲の大きさ $(d$ の範囲 $)$ ごとに整 理した結果を示している。図-6の縦軸は正側に振れ ると検証範囲に含まれる NDVI の平均值の方が高い 值を示す。横軸は数值が小さくなるにつれて植生分 布変移軸の近くへ検証範囲が限定されていることを 表す. 図-6（a）は破線で 2000 年での正の植生分布 変移軸の抽出方法の適用性の検証結果を示してい る. 図-6（a）の破線では検定統計量の值が正側に振 れ，検証範囲 $870 \mathrm{~m}$ 以下では正側の有意水準 5\% で 有意な結果が得られた，図-6（b）では実線で 2013 年現在での検証結果を示している。図-6（b）の実線 では有意水準 $5 \%$ で $1290 \mathrm{~m}$ 以下の検証範囲で正側に 有意な結果が得られる傾向が見られる。

図-7に負の植生分布変移軸の検証結果を示す，図 -7 (a) の破線での 2000 年で負の植生分布変移軸と して抽出された箇所での検証結果は, すべての検証 範囲で正側の有意水準 5\%を超える結果を示した. 図-7（b）の実線で示した 2013 年に負の植生分布変 移軸として抽出された箇所に执いては，1290m 以下 の検証範囲で有意水準 5\%を超える結果を示した.

\section{d）植生分布変移軸の変遷の調査}

いずれの時期に抢いても，正・負の植生分布変移 軸の近傍に NDVI の高い画素が集積する結果となっ た。これらの空間的な特徵を有する箇所に対して 2 時期の NDVIを用いた検証結果を比較することで, 抽出箇所の周辺の植生分布の連なりの変遷を調査す る. 考え方を図-8に示す. 図-8 のオレンジ色で示 


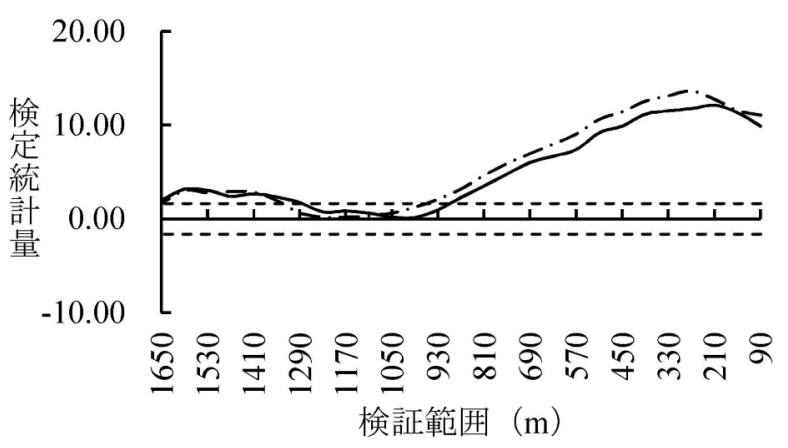

(a) 2000年

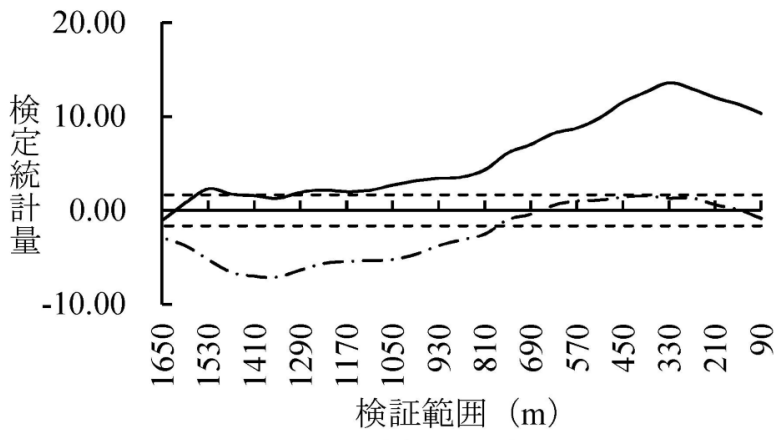

(b) 2013 年

\section{-・・-2 2000年のNDVI — 2013年のNDVI \\ - - - - 有意水準 5\%}

図-6 正の植生分布変移軸の検証結果

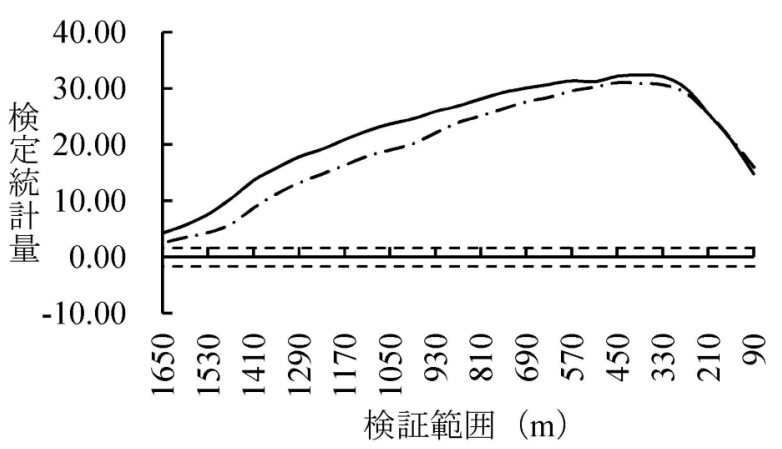

(a) 2000 年

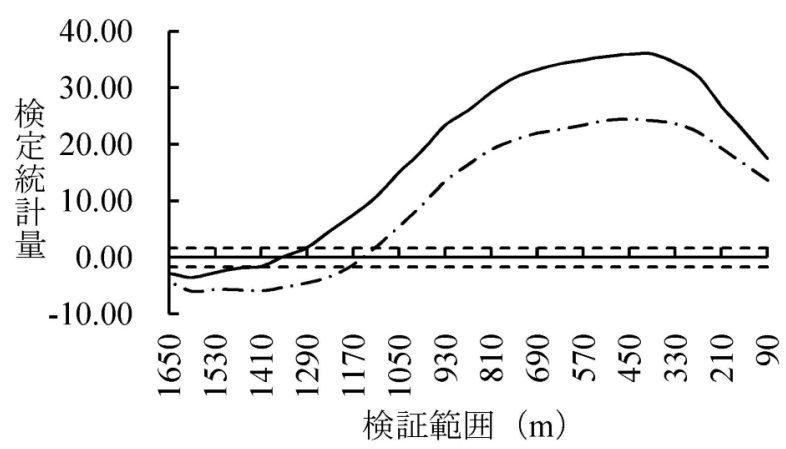

(b) 2013 年

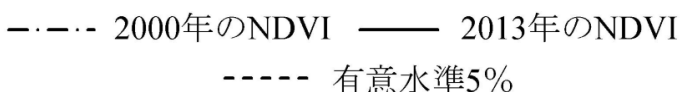

図-7 負の植生分布変移軸の検証結果

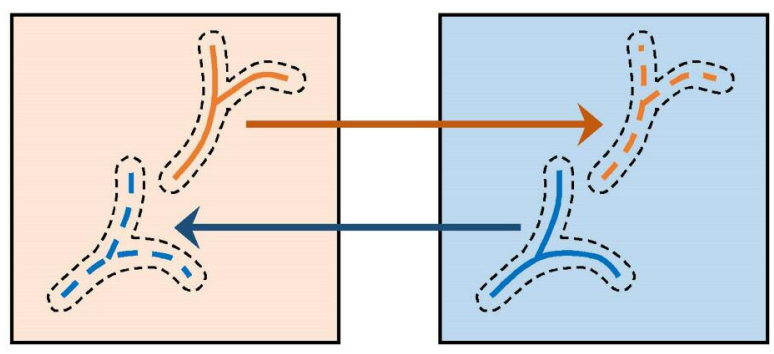

(a) 2000 年の NDVI

(b) 2013 年の NDVI

2000 年の

2013 年の

植生分布変移軸

植生分布変移軸

図-8 土地被覆状態の変遷の調査方法

す 2000 年の植生分布変移軸では, 前項にて検証範囲 と比較範囲に含まれる 2000 年の NDVIを比較する ことで植生分布変移軸の抽出手法の適用性を検証し たこととなる。そこで，次に同位置の 2013 年の NDVI を使用し, 同様に検証する。 2000 年と 2013 年 の検証結果を比較することで，2000 年に抽出された 植生分布変移軸の周辺の土地被覆状態がどのように 変化したかを明らかにする。図-8の青色で示す 2013 年の植生分布変移軸では, 2013 年の NDVI で抽 出手法の適用性を検証するとともに, 2000 年の NDVI を使用することで 2013 年の植生分布変移軸の 周辺の土地被覆が過去ではどのような状態であった かを調査することになる。

図-6（a）の実線は 2000 年の正の植生分布変移軸 周辺での 2013 年の NDVIの分布状態を示している. 図-6（a）からは2000 年の正の植生分布変移軸の周 辺において，2000 年と 2013 年の NDVI で同様の傾 向を示すことが確認できる。2000 年の NDVIより抽 出された正の植生分布変移軸は, 2013 年においても 抽出箇所の周辺にNDVIの高い画素が集まる傾向を 維持していることが推測される。図-6（b）の破線で 示した 2013 年の正の植生分布変移軸周辺での 2000 年の NDVIの分析結果では，検定統計量の值が正側 で有意な結果を得られなかった。図-3の正の SSC の変遷を考慮すると，2013 年の正の植生分布変移軸 の周辺は，2000 年の段階では近傍に限らず，広い範 囲でNDVIの高い值を示す地域であったことが推測 される。つまり，2013 年の正の植生分布変移軸は 2000 年から 2013 年の間に抽出箇所の近傍と遠方と の NDVIの差が大きくなることによって植生分布変 移軸として抽出されたことが考えられる。

図-7（a）の 2000 年の負の植生分布変移軸では 2000 年と 2013 年ともに, 抽出箇所の周辺に NDVI の高い画素が集まる傾向を確認できる。図-7（b）の 2013 年に負の植生分布変移軸として抽出された箇所 においては，2000 年の NDVI で $1050 \mathrm{~m}$ 以下の検証範 


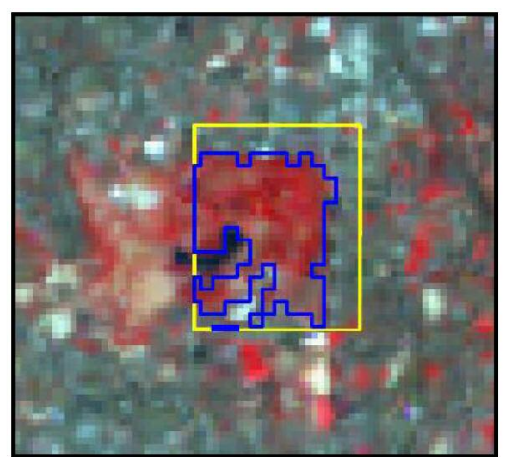

(a) 2000 年

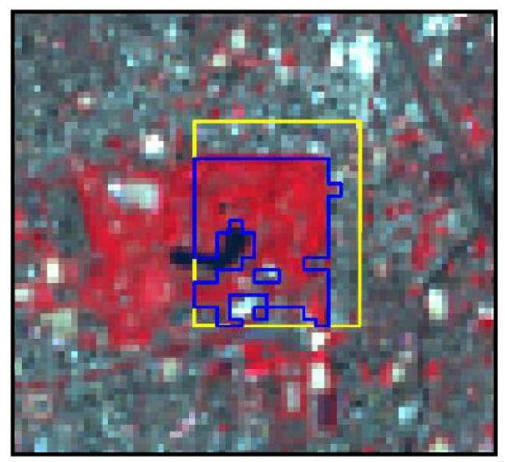

(b) 2013 年

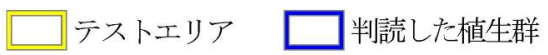

図-9 フォールスカラー画像と判別した植生群の領域

表-1 植生群の一致率について (a) 2000 年

\begin{tabular}{|c|c|c|c|}
\hline & \multicolumn{2}{|c|}{ 判読した植生群 } \\
\hline & & 植生 & 植生以外 \\
\hline \multirow{2}{*}{ 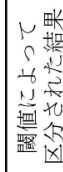 } & 植生 & 91.2 & 15.1 \\
\hline & 植生以外 & 8.8 & 84.9 \\
\hline
\end{tabular}

\begin{tabular}{|c|c|c|c|}
\hline & \multicolumn{2}{|c|}{ 判読した植生群 } \\
\hline & & 植生 & 植生以外 \\
\hline 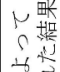 & 植生 & 84.0 & 15.3 \\
\hline 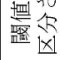 & 植生以外 & 16.0 & 84.7 \\
\hline
\end{tabular}

囲とした場合に有意水準 5\%を超える結果を示した。 2013 年での負の植生分布変移軸の周辺では 2000 年 から 2013 年に移り変わることで, NDVI の高い画素 の集まりが広がる傾向を確認できる.

\section{（3）植生群の推定結果による比較}

a) 植生群の比較

対象領域において，2000 年から 2013 年に移り変 わることで, 正の植生分布変移軸は平野部から山岳 部に移動し, 負の植生分布変移軸は河川敷を中心に 都市部で広く分布する傾向が見られた。正・負の SSC の変遷と併せて考えると, 2000 年から 2013 年 にかけて, 植生被覆量の多い箇所が集まる領域が分 断されてきた可能性がある。そこで本研究では，植 生分布変移軸の変化の特性を把握するためにまとま りのある植生分布を植生群として試験的に抽出し,
植生分布変移軸を構成する植生群の構成の推移を調 査した。具体的には，大阪城公園などの大規模な緑 地や農業振興地域での農地を含む地域を，2 時期を 通じて植生分布の変化が少ない地域と見なし, テス トエリア（総面積：4. $6 \mathrm{~km}^{2}$ ) として選定した。大阪 府が 2002 年 10 月 17 日および 11 月 17 日撮影の航 空写真の目視判読により作成した「みどりの分布図 デー夕」（空間分解能：1m×1m）における植生面を 参照用のデータとした上で，テストエリアにおける 2000 年の衛星データのフォールスカラー画像を基に 植生群の領域を確定させた。2013 年の場合も同様に 「みどりの分布図データ」での植生面や 2013 年観測 の衛星データを参考に, 植生群の領域を確定させた。 図-9に確定した植生群のエリアの例を示す。植生群 の領域を含むテストエリア内において, 2000 年, 2013 年それぞれにおいて NDVI を対象に䦨值を変動 させ，植生群と最も一致する值を決定した。表-1に 結果を示す。表-1は閾值によって 2 つの群に区分さ れた結果と, あらかじめ設定したテストエリア内の 植生群とそれ以外の領域との一致率をエラーマトリ クスで表したものである。この閾值を使用して全域 で区分された領域を比較のための植生群と定義し, その分布を調査した。

\section{b）植生群の配置密度での比較}

図-10に，植生群の規模と構成について整理した。 図-10では縦軸に対象とする範囲における植生群の 箇所数の累積值を調査範囲の面積で除した密度で表 し，横軸に植生群の規模を対数值として表現してい る. 対象領域の全体での植生群の構成を示す図-10 (a) では, $0.004 \mathrm{~km}^{2}$ から $0.02 \mathrm{~km}^{2}$ 程度の植生群が 2013 年で減少している傾向がみられる。その一方 で，図-10（b） は正の植生分布変移軸から $330 \mathrm{~m}$ の範 囲での植生群の構成を調查したものであるが, 対象 領域の全体での傾向よりも大きな, $0.03 \mathrm{~km}^{2}$ から $0.2 \mathrm{~km}^{2}$ 程度の植生群が減少する傾向がみられる。正 の植生分布変移軸の変化がみられた対象領域の北部 や東部の地域はニュータウン型の開発や高速道路が 新たに整備された地域でもある。図-10（b）でみら れる規模の大きな植生群の減少する傾向は都市整備 により大規模な植生群が縮小や分断されたことを示 唆する結果とも考えられる。図-10（c）は負の植生 分布変移軸から $450 \mathrm{~m}$ の範囲での結果である。図-10 (c) では $0.007 \mathrm{~km}^{2}$ から $0.1 \mathrm{~km}^{2}$ 程度の規模の植生群 が減少する傾向が確認できる。負の植生分布変移軸 のまわりの植生群は $0.004 \mathrm{~km}^{2}$ から $0.02 \mathrm{~km}^{2}$ の範囲で は対象領域全体と似た傾向を示すものの, 特に $0.01 \mathrm{~km}^{2}$ から $0.02 \mathrm{~km}^{2}$ の規模の植生群の箇所数が大 幅に減少していることがわかる。都市内で, 植生被 


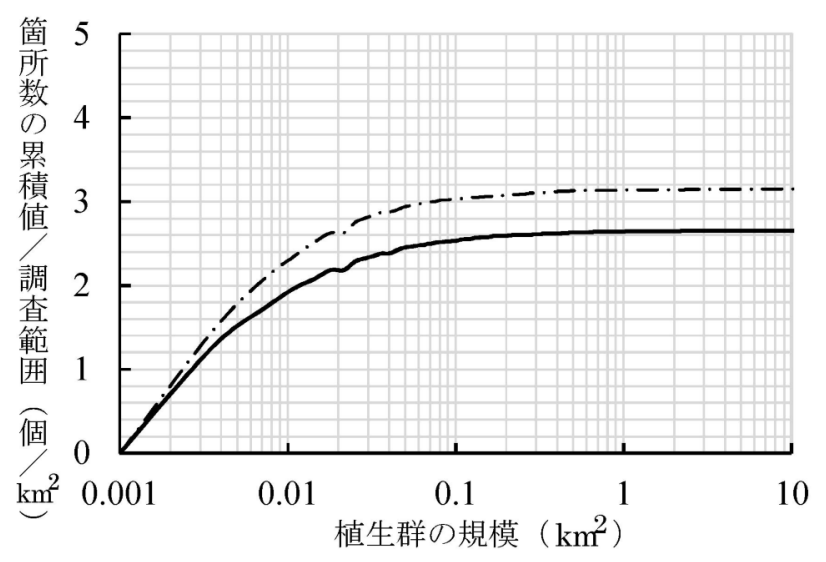

(a) 対象領域全体

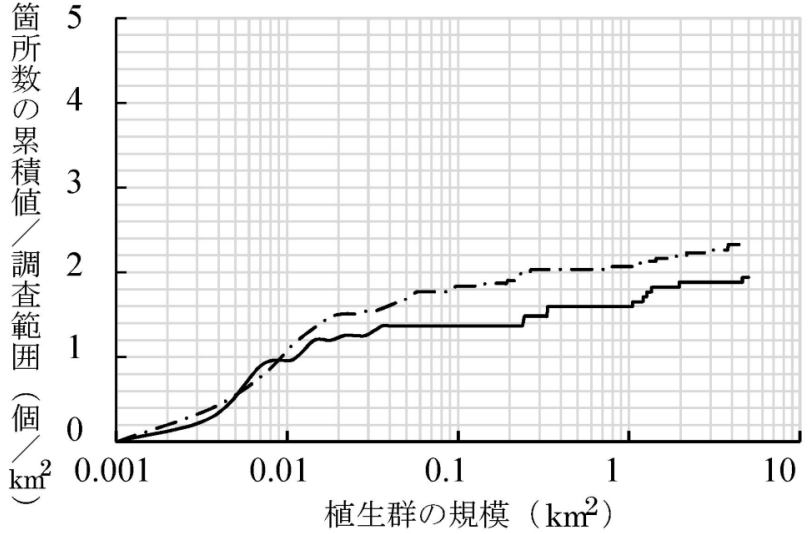

(b) 正の植生分布変移軸周辺

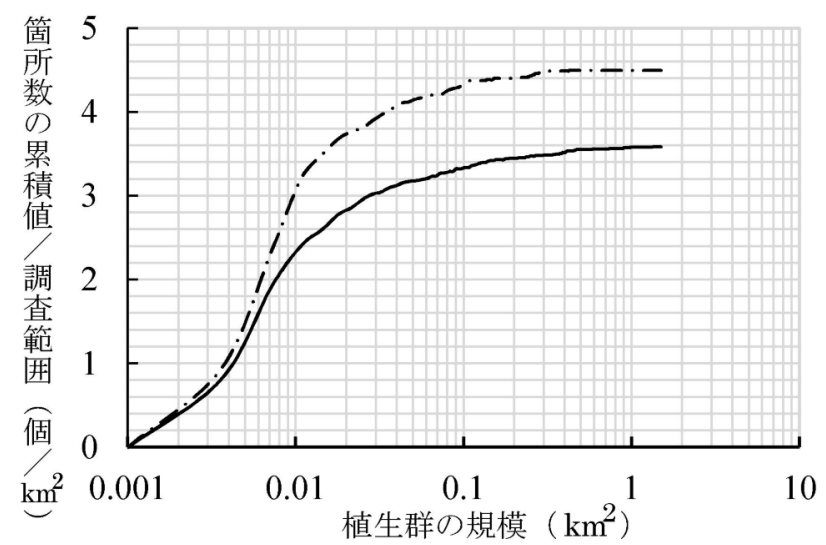

(c) 負の植生分布変移軸周辺

図-10 植生群の配置密度の検証結果

覆量の多い箇所が集まるような希少な領域において も植生群の規模の構成が変化したことを意味してい る。

\section{5. まとめ}

観測時期の異なる 2 時期の衛星データから算出し たNDVIに空間分析手法を適用し，植生分布の空間 的な集積の度合いを表す SSC を作成した上で，水文 解析を応用することで植生被覆量の多い箇所から少 ない箇所へと植生分布が空間的に連なる箇所として 植生分布変移軸を抽出した. $\mathrm{SSC}$ の 2 時期での推移 を確認すると，植生分布がまばらに存在するような 箇所で変化が見られることがわかった. SSCの層数 の比較から 2000 年から 2013 年では近傍から遠方に 渡って植生被覆量の多いと判定される箇所が山岳部 に限定される傾向を確認した。ささらに，植生分布変 移軸周辺での NDVI の統計的な特性と植生群の規模 を比較したところ, 縮小や分断といった変化が植生 分布の空間的な連なりに影響を及ぼしている可能性
が示唆された。なお，本研究での手法により得られ る植生分布変移軸は, 対象とする地域の範囲やその 地域の植生の分布状態によって生成される位置が変 化することが考えられる。したがって，他の地域で の経年変化の分析に本分析手法を適用する場合はそ の地域ごとに植生分布変移軸の有する特性を整理す る必要がある。

本研究では 2 時期の衛星デー夕を採用し分析を進 めた。次の展開として，2000 年以前に観測された衛 星デー夕を本分析手法に適用し，その結果を比較す ることによってより長期間にわたった植生分布の連 なりの変遷を把握することを考えている，また，日 本国内の都市域のような地域では Landsat などで観 測された衛星データの 1 画素内にさまざまな土地被 覆状態が混在する可能性がある。本分析手法に高空 間分解能の衛星デー夕を採用することで, 都市域内 おける植生分布の空間的な連なりの特性が明らかに なることが期待できる。

\section{参考文献}

1）国土交通省：国土のグランドデザイン 2050, 2014 年, 
<http://www.mlit.go.jp/common/001047113.pdf >，（入手 2015. 10. 22).

2）国土交通省・国土交通政策研究所：オープンスペース の実態把握と利活用に関する調査研究，2012 年，<htt p://www.mlit.go.jp/pri/houkoku/gaiyou/pdf/kkk106.pdf >, （入手 2015. 10.22）。

3）国道交通省 都市局公園緑地・景観課：新たな時代の都 市マネジメントに対応した都市公園等のあり方検討 会中間とりまとめ, 2015 年, <http://www.mlit.go.jp/co mmon/001106065.pdf >, （入手 2015. 10.22）.

4）国土交通省都市・地域整備局都市計画課・公園緑地課： 新編緑の基本計画ハンドブック，p. 234，社団法人日 本公園緑地協会, 2007.

5）国土交通省：「環境の世紀」における公園緑地の取り 組み, 2004 年, <http://www.mlit.go.jp/crd/park/joho/d1/k ankyo/ >, (入手 2015. 10.22).

6）大阪府：みどりの大阪推進計画, 2009 年, <http://ww w.pref.osaka.lg.jp/attach/217/00019983/ful.pdf >, （入 手 2015. 10. 22).

7）熊谷樹一郎，前田壮亮：事前広域評価支援を目的とし た植生分布に関する空間分析方法の開発，土木学会論 文集 F, Vol. 64, No. 3，pp. 237-247， 2008.

8) Ustin, S. L. : Remote Sensing for Natural Resource
Management and Environmental Monitoring, Manual of Remote Sensing Third Edition, Volume 4, John Wiley and Sons, 2004.

9) 竹内章司：衛星画像の植生指標による画素内縁被率の 推定, 写真測量とリモートセンシング, Vol. 26, No. 4, pp. 4-12, 1987.

10）羽柴秀樹，亀田和昭，田中總太郎，杉村俊郎：高分解 能衛星画像データによる都市域の小規模植生分布の 抽出, 土木学会論文集, No. 685 / VII-20, pp. 27-39, 2001.

11）平野勇二郎, 安岡善文, 柴崎亮介：都市域を対象とし たNDVIによる実用的な緑被率推定, 日本リモートセ ンシング学会誌, Vol.22, No.2, pp. 163-174, 2002.

12) Ord, K. and Getis, A. : Local spatial autocorrelation statistics: distributional issues and an application, Geographical Analysis, Vol. 27, No. 4, pp. 286-306, 1995.

13) Kumagai, K. : Verification of the analysis method for extracting the spatial continuity of the vegetation distribution on a regional scale, Computers, Environment and Urban Systems, Vol. 35, pp. 399-407, 2011.

(2015. 10. 26 受付)

\title{
TREND ANALYSIS OF THE SPATIAL AGGLOMERATION OF VEGETATION DISTRIBUTIONS USING SATELLITE IMAGERY
}

\author{
Hitoshi UEMATSU, Yuka MATSUDA and Kiichiro KUMAGAI
}

\begin{abstract}
Vegetation in urban areas has several functions such as the conservation of ecosystem, the reduction of urban heat island phenomenon, etc. The spatial continuity of vegetation distributions is required for the effective performance of the functions. In order to make locational planning of greenery areas, it is necessary to grasp the long-term change of the greenery areas. We have developed a spatial analysis method for detecting the continuity of vegetation distributions on a regional scale using remotely sensed data. The method consists of local spatial autocorrelation analysis, an overlay analysis, and a hydrological analysis with the Normalized Difference Vegetation Index (NDVI) adopted as the proxy of vegetation abundance. In this study, we apply the spatial analysis to two types of remotely sensed data acquired in 2000 and 2013 , respectively. We discuss the long-term change of the spatial continuity of vegetation distributions through comparing between the results of the analysis. As a result, a change of the continuity of vegetation distributions were found to be involved in areas of large-scale urban development in study area.
\end{abstract}

